\title{
SELECTION AND USE OF EFFICIENT BACTERIAL STRAINS FOR CHROMIUM BIOSORPTION IN TANNERY EFFLUENT
}

\author{
Lalith Varadhan $\mathbf{S}^{\mathbf{1}}$ and Mohan $\mathrm{S}^{\mathbf{2}}$ \\ ${ }^{1}$ Environmental Engineering, Department of Civil Engineering, Annamalai University, India \\ ${ }^{2}$ Department of Civil Engineering, Annamalai University, India \\ DOI: http://dx.doi.org/10.24327/ijrsr.2017.0803.0106
}

\section{ARTICLE INFO}

\section{Article History:}

Received $06^{\text {th }}$ December, 2015

Received in revised form $14^{\text {th }}$

January, 2017

Accepted $23^{\text {rd }}$ February, 2017

Published online $28^{\text {th }}$ March, 2017

\section{Key Words:}

Tannery effluent, Biological treatment, Bacteria, Chromium (VI), Biosorption.

\begin{abstract}
Tanning industry is one of the large-scaled industry in India which generals high turbid, colour and foul smelling wastewater together with toxic heavy metals including chromium and thus leading to environmental pollution. The present investigation emphasise the need of biological treatment of tannery effluent as an alternative a cost-efficient and eco-friendly approach for the efficient removal of chromium toxicity. In the present study a total of eight bacterial (4 gram positive and 4 gram negative) were isolated and the chromium resistance of the same was determined. Gram positive bacteria exhibited higher chromium tolerance than Gram negative bacteria whereas Bacillus and Staphylococcus, as Gram positive bacteria exhibited the higher chromium tolerance. The biosorption of $\mathrm{Cr}$ (VI) by these isolates revealed that the isolate Bacillus adsorbed the chromium ions to a higher level than Staphylococcus strains and the $\mathrm{pH}$ and temperature plays a vital role in biosorption of $\mathrm{Cr}(\mathrm{VI})$. It is concluded that the biological treatment of tannery wastewater together with chromium resistant bacterial strains will be a cost-effective, eco-friendly, alternative approach for the bioremediation of chromium in heavy metal.
\end{abstract}

Copyright (C) Lalith Varadhan S and Mohan S, 2017, this is an open-access article distributed under the terms of the Creative Commons Attribution License, which permits unrestricted use, distribution and reproduction in any medium, provided the original work is properly cited.

\section{INTRODUCTION}

Tanning is the chemical process that converts animal hides and skin into leather and related products. The transformation of hides into leather is usually done by means of tanning agents and the process generates highly turbid, coloured and foul smelling wastewater (Bulian and Kral, 2011). The major components of the tannery effluent include sulphide, chromium, volatile organic compounds, large quantities of solid waste, suspended solids like animal hair and trimmings. For every kilogram of hides processed, 30 liters of effluent is generated and the total quantity of effluent discharged by Indian industries is about $50,000 \mathrm{~m}^{3}$ /day (Jalandhar, 2008).

Chromium salts used during the tanning process generate two forms of chrome; Hexavalent chromium and trivalent chromium. Hexavalent chromium is highly toxic to living organisms even at low concentration causing carcinogenic effect (Frankfurt, 2002). Trivalent chromium may be present in the waste or can be produced from the Hexavalent chromium by chemical treatment. Soluble trivalent chromium causes toxicity in anaerobic digestion due to the accumulation of the metal in the intracellular fraction of biomass (Jalandhar, 2008). The environmental protection regulations stipulate that industries are not allowed to emit chromium in the wastewater. Effluents from raw hide processing tanneries, which produce wet blue, crust leather or finished leather, contain compounds of trivalent chromium $(\mathrm{Cr})$ in most cases. Thus, removal of chromium from the wastewater is very important. The uncontrolled release of tannery effluents to natural water bodies increases health risks for human beings and environmental pollution. Tannery wastewater is difficult to treat because of complex characteristics like high BOD, COD, suspended solids, sulphide and chromium. Among the different treatments of tannery effluent, the biological treatment of tannery effluent is considered as a cost-effective and ecofriendly attractive alternative to the present physico-chemical methods of treatment (Reid et al., 1985).

Microorganisms possess a metabolic machinery of immense versatility aiding the breakdown of pollutants. In the course of evolution and rapid industrialization, microorganisms have been exposed to numerous chemicals and thereby adapted to their presence by developing necessary enzymes which aid in metabolizing such compounds. Biological reductions of chromium using indigenous microorganisms offer a costeffective and environmentally compatible technology (Camargo et al., 2003) Megharag et al. (2003), worked on the 
reduction of chromium using Arthrobacter sp. and Bacillus sp. from tannery effluents in Australia. Most of the researchers who done their investigations using chromium aqueous solutions, have not shown significant or complete removal of the metal. The occurrence of metal resistant bacteria in anthropogenically polluted sites is also documented (Diels and Mergeay, 1990).

Biosorption is widely used for metal removal from industrial effluents and subsequent recovery (Vieira and Volesky, 2000). The microbial biomass has an inherent capacity to adsorb chromium due to the presence of functional groups such as $\mathrm{NH}_{2}$, $-\mathrm{COOH},-\mathrm{SH}$, and -OH on microbial cell walls, which act as binding sites for interaction of metal ions (Kuyucak and Volesky, 1998). The major advantages of biosorption technology are their effectiveness in reducing the concentration of chromium metal ions to very low levels and the use of inexpensive biosorbent materials (Volesky, 1994).

Hence, the present study has been undertaken with an aim to screen the natural bacterial strains from the tannery effluent for chromium resistance and use the same for the development of a bioremediation technology.

\section{MATERIALS AND METHODS}

\section{Collection of tannery effluent}

Effluent sample was collected in the plastic containers from the outlet of a tannery industry situated in vaniyambadi of vellore District, Tamil Nadu. The physico-chemical characteristics of the same were analyzed using standard methods (APHA, 2005). The effluent was stored at $4 \mathrm{C}$ in order to avoid changes in the characteristics, during storage.

Table 3 Physico-chemical characteristics of raw tannery effluent

\begin{tabular}{ccc}
\hline S.no & Parameter & Initial values \\
\hline 1. & $\mathrm{pH}$ & 9.5 \\
2. & TDS mg/L & 12,200 \\
3. & Electrical Conductivity $\mathrm{ms} / \mathrm{cm}^{2}$ & 19,000 \\
4. & Odour & Objectionable \\
5. & Colour & Brownish black \\
6. & Turbidity NTU & 390 \\
7. & Total Hardness mg/L & 5400 \\
8. & Chlorides & 1462 \\
9. & DO mg/L & 18 \\
10. & BOD mg/L & 1260 \\
11. & Chromium mg/L & 140 \\
\hline
\end{tabular}

\section{Isolation and identification of Cr-resistant bacteria}

Tannery effluent, samples were serially diluted upto $10^{-6}$ in sterile phosphate buffer $(\mathrm{pH}$ 7.2) and inoculated into Nutrient agar medium amended with $50 \mu \mathrm{g} / \mathrm{ml}$ of $\mathrm{Cr}$ (VI) by spread plate method. A filter-sterilized solution of $\mathrm{K}_{2} \mathrm{Cr}_{2} \mathrm{O}_{7}$ was used as the source of $\mathrm{Cr}$ (VI), which was added to the sterile melted Nutrient agar medium to prevent problems associated with autoclaving chromate containing solutions (Babich et al., 1982). The inoculated plates were incubated at $37 \mathrm{C}$ for $48 \mathrm{hrs}$. After the incubation period, the plates were observed for the growth of microorganisms. Morphologically different colonies were picked and purified by many round of restreaking. The isolates were subjected to different morphological, physiological and biochemical characterization as mentioned in Bergey's manual of determinative bacteriology, $8^{\text {th }}$ edition for genus and species identification.

\section{Growth of efficient bacterial strains on nutrient broth medium with different concentrations of chromium}

Hundred $\mathrm{ml}$ of nutrient broth medium was prepared, autoclaved and amended with different concentrations (50, 100, 150, 200 and $250 \mathrm{mg} / \mathrm{L}$ ) of filter streilised $\mathrm{K}_{2} \mathrm{Cr}_{2} \mathrm{O}_{7}$ solution and dispensed in $250 \mathrm{ml}$ conical flasks, separately. One $\mathrm{ml}\left(1 \times 10^{7}\right.$ $\mathrm{CFU} / \mathrm{mL}$ ) of each bacterial isolates was added into the medium, separately and incubated at $35 \mathrm{C}$ for $24 \mathrm{hr}$ under shaking condition (150 rpm). Bacterial growth was monitored by reading the absorbance in spectrophotometer at $660 \mathrm{~nm}$.

\section{Growth of microorganisms and Biosorption}

Bacillus sp. and staphylococcus sp. was inoculated separately to sterilized nutrient broth, incubated at $37 \mathrm{C}$ for $24 \mathrm{hrs}$ in under shaking condition (150 rpm). At the end of incubation, the biomass was separated individually from medium by centrifugation ( $5000 \mathrm{rpm} \times \mathrm{g}$ ) for five minutes and it was kept in the oven at $50 \mathrm{C}$ to remove the free water as much as possible. Then, the cells were suspended in deionized water separately in order to use it in the biosorption experiment. 100 $\mathrm{ml}$ solutions containing $100 \mathrm{mg} / \mathrm{L} \mathrm{Cr}^{6+}$ were prepared from stock solution containing $1 \mathrm{~g} / \mathrm{L} \mathrm{Cr}^{6+}\left(\mathrm{K}_{2} \mathrm{Cr}_{2} \mathrm{O}_{7}\right)$. Then $2.0 \mathrm{~g}$ microorganism was added to the solution and adsorption of metal was investigated at different $\mathrm{pH}$ values adjusted by using $1 \mathrm{~N} \mathrm{HCl}$ and $1 \mathrm{~N} \mathrm{NaOH}$ at $37 \mathrm{C}$. The solution containing the biomass was agitated in a shaker of $150 \mathrm{rpm}$ during the adsorption.

Table 2 Morphological and biochemical characteristics of chromium resistant bacteria

\begin{tabular}{|c|c|c|c|c|c|c|c|c|c|c|c|c|c|c|c|c|c|c|}
\hline 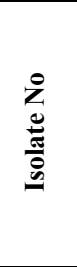 & 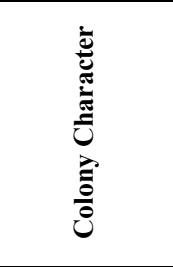 & 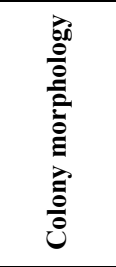 & $\begin{array}{l}\stackrel{\Xi}{\Xi} \\
\frac{\Xi}{\tilde{D}} \\
\bar{\Xi} \\
\end{array}$ & 兰 & 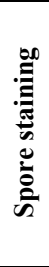 & 泀 & 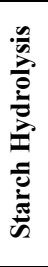 & لَّ & 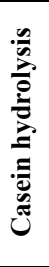 & 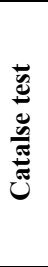 & 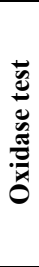 & 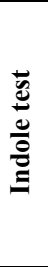 & 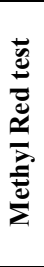 & 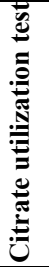 & 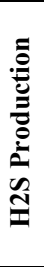 & 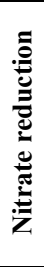 & 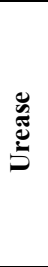 & Tentative identificatioon \\
\hline VB-1 & Cream colour & Irregular & Rod & + & + & + & + & + & - & + & + & + & + & + & - & - & - & Bacilus megatherium \\
\hline VB-2 & White & Flat & Rod & + & + & + & + & + & - & + & + & - & + & - & - & + & - & Bacillus cereus \\
\hline VB-3 & $\begin{array}{l}\text { Slimy cream } \\
\text { colour }\end{array}$ & Raised & Rod & + & + & - & + & + & + & - & - & - & - & + & - & - & - & Lactobacillus sp. \\
\hline VB-4 & White & Flat & Coccal & + & - & + & + & - & - & - & - & - & + & - & + & + & - & Staphylococcus sp. \\
\hline VB-5 & Slimy & Flat & Rod & - & - & + & - & + & + & + & + & - & - & + & - & - & - & Pseudomonas putida \\
\hline VB-6 & Slimy & Flat & Rod & - & - & + & - & + & + & + & + & - & - & + & - & + & - & Pseudomonas erginosa \\
\hline VB-7 & White & Flat & Rod & - & - & - & - & + & - & + & - & + & - & - & + & + & - & Flavobacterium sp. \\
\hline VB-8 & Light cream & Irregular & Rod & - & - & + & - & - & - & + & + & - & - & + & - & - & - & Alcaligenes sp. \\
\hline
\end{tabular}


Samples taken at predetermined intervals were centrifuged and supernatants were analyzed. The analysis of $\mathrm{Cr}^{6+}$ ion was carried out by using Atomic Adsorption Spectrophotometer (Perkin-Elmer) at $0.01 \mathrm{ppm}$ sensitivity level after dilution of the samples (Sultan and Hasnain, 2007). By taking the determined optimum conditions into consideration, the capacity of microorganism to remove the mentioned metal from the tannery effluent was determined with the same method.

Table 3 Growth of bacterial strains on Chromium amended solid medium at different concentrations

\begin{tabular}{cccccc}
\hline \multirow{2}{*}{ ISOLATES } & \multicolumn{5}{c}{$\mathrm{K}_{\mathbf{2}} \mathrm{Cr}_{2} \mathrm{O}_{7}(\mathbf{m g} / \mathbf{L})$} \\
\cline { 2 - 6 } & $\mathbf{5 0}$ & $\mathbf{1 0 0}$ & $\mathbf{1 5 0}$ & $\mathbf{2 0 0}$ & $\mathbf{2 5 0}$ \\
\hline VB 1 & + & + & + & - & - \\
VB 2 & + & + & + & + & + \\
VB 3 & + & + & - & - & - \\
VB 4 & + & + & + & + & + \\
VB 5 & + & + & - & - & - \\
VB 6 & + & + & - & - & - \\
VB 7 & + & - & - & - & - \\
VB 8 & + & - & - & - & - \\
\hline
\end{tabular}

\section{RESULT AND DISCUSSION}

The tannery effluent sample was collected in the plastic containers from the outlet of a tannery industry situated in vaniyambadi of vellore district, Tamilnadu. The effluent released from the main outlet of tannery is brownish black in colour with an offensive odour whereas the temperature is about $38^{\circ} \mathrm{C}$. The physico-chemical analysis of the tannery effluent revealed that the $\mathrm{pH}$ of the effluent sample was found to be 9.5 whereas the chromium level in raw effluent was found be $140 \mathrm{mg} / \mathrm{L}$ which are above the BIS limit, (2009) (Table 3). Fadali et al., (2005) reported that the $\mathrm{pH}$ of the tannery effluent was found to be 10 which was above the permissible limit and suggested that this alkaline $\mathrm{pH}$ of the effluent could affect the biological property of the receiving water bodies. Chromium level in the raw effluent was found to be $140 \mathrm{mg} / \mathrm{L}$ which was higher than the amount prescribed by BIS $(0.5 \mathrm{mg} / \mathrm{L})$. The extremely high concentration of chromium in the raw tannery effluent has already been reported by Krantz and Kifferstein (2002) and Tripathi et al. (2011).

\section{Isoltion and selection of Chromium tolerant bacterial strains}

In the present study 8 indigenous bacterial strains were isolated from tannery effluent and designated as "VB" series and numbered randomly (VB-1 to VB-8). The genus and species characterization of the isolates were done according to Bergey's manual of determinative bacteriology $8^{\text {th }}$ edition and they were identified as Bacillus megaterium, Bacillus cereus, Lactobacillus sp., staphylococcus sp., Pseudomonas putida., Pseudomoans aeruginosa, Flavobacterium sp. and Alcaligenes $s p$, respectively. Among the 8 bacterial strains, the strain Bacillus cereus and the strain Staphylococcus $s p$. were found to tolerate the chromium level upto $250 \mathrm{mg} / \mathrm{L}$ amended in nutrient agar medium. Interestingly, it was observed that the gram positive bacterial strains were able to tolerate higher concentration of chromium level in tannery effluent when compared to the gram negative bacterial strains. The occurrence and activities of chromium tolerant bacterial strains from tannery effluent has already been reported by Basu et al. (1997), Srinath et al. (2002), Megharaj et al. (2003), Zhiguo Hea et al. (2009), Soha and Sahar (2010).
Temperature and $\mathrm{pH}$ play a vital role in the biosorption efficiency of $\mathrm{Cr}$ (VI) ions by the effluent bacterial isolates. From the optimization study, it was observed that the biosorption of $\mathrm{Cr}$ (VI) by the bacterial isolates varied with different levels of $\mathrm{pH}$ and temperature, tested. The $\mathrm{pH}$ at 7.0 level and temperature at $35^{\circ} \mathrm{C}$ recorded the highest biosorption of $\mathrm{Cr}$ (VI) by the two bacterial isolates, namely, Bacillus cereus and Staphylococcus sp.

In general, potential microorganism's especially bacterial species could remove heavy metals, including, chromium from solutions by biosorption or bioaccumulation or both. A variety of mechanisms exist for the removal of heavy metals from aqueous solution by bacteria, fungi, ciliates, algae, mosses, macrophytes and higher plants (Sultan and Hasnain, 2007; Pattanapipitpaisal et al., 2002). Biosorption largely involves physical adsorption followed by chemical bondage and does not require energy. Once, the metal ions are diffused on the cell surface, they bind to the sites which exhibit chemical affinity for the metal. It is a passive accumulation process which may include adsorption, ion-exchange, complexation, chelation, and microprecipitation.

Chromium resistant bacteria have been isolated from tannery effluents by several groups (Rehman et al., 2008). In the present investigation both Bacillus sp. and Staphylococcus sp. were found to be highly resistant to chromium ions. Under the optimum conditions (Table 4 \& 5) the highest biosorption efficiency was 97 percent $\left(\mathrm{pH} 7\right.$ ) and 98 percent (Temp $35^{\circ} \mathrm{C}$ ) for Bacillus sp. and 92 percent and 93 percent were seen at $\mathrm{pH}$ 7 and temperature $35^{\circ} \mathrm{C}$, respectively for Staphylococcus sp. It was observed that both bacteria not only exhibited the ability to survive in contaminated wastewater but also demonstrated a marked increased in remediation of toxic $\mathrm{Cr}$ (VI)

Table 4 Effect of $\mathrm{pH}$ on biosorption of Cr (VI) by Bacillus spp and Staphylococcus sp

\begin{tabular}{ccc}
\hline \multirow{2}{*}{$\mathbf{p H}$} & \multicolumn{2}{c}{ Cr (VI)* adsorption efficiency (\%) } \\
\cline { 2 - 3 } & Bacillus & Staphylococcus \\
\hline 5.0 & 88 & 83 \\
6.0 & 92 & 87 \\
7.0 & 97 & 92 \\
8.0 & 95 & 88 \\
\hline
\end{tabular}

*Initial concentration of chromium (VI) $150 \mathrm{mg} / \mathrm{L}$

Table5 Effect of temperature on biosorption of $\mathrm{Cr}$ (VI) by Bacillus spp and Staphylococcus spp

\begin{tabular}{ccc}
\hline \multirow{2}{*}{ Temperature $^{\mathbf{0}} \mathbf{C}$} & \multicolumn{2}{c}{ Cr (VI)* } \\
\cline { 2 - 3 } & Bacillus & Staphylococcus \\
\hline 25 & 92 & 82 \\
30 & 94 & 85 \\
35 & 98 & 93 \\
40 & 95 & 87 \\
\hline
\end{tabular}

*Initial concentration of chromium (VI) $150 \mathrm{mg} / \mathrm{L}$

Microbially catalyzed reduction of $\mathrm{Cr}$ (III), was first reported with Pseudomonas sp. (Romanenko and Korenken, 1997). Since then, significant progress has been made towards the understanding of the processes that controlling the enzymatic reduction of $\mathrm{Cr}$ (VI) in gram-negative bacteria, especially those belonging to the genera Pseudomonas, Desulfovibrio and Shewanella (Ackerley et al., 2004). Several gram-positive bacteria have also been known to reduce $\mathrm{Cr}$ (VI) including several members of the genus Bacillus (Camargo et al., 2003). The cell wall of gram positive bacteria is highly efficient metal 
chelator and in Bacillus subtilis, the carboxyl group of the glutamic acid of peptidoglycan was the major site of metal deposition. Teichoic and Teichuronic acids were important binding sites in Bacillus licheniformis (Gadd, 1990). Staphylococcus $s p$. is also a Gram positive bacterium and has similar cell wall properties as of other Gram-positive bacteria.

\section{CONCLUSION}

The results of the present study clearly revealed the positive role of gram positive bacteria, namely, Bacillus sp. and Staphylococcus sp. on the biosorption of chromium in tannery effluent. This biological treatment technology facilitates the tanners in tackling the pollution problem of tannery wastewater. Moreover, the bioprocesses are found to be more cost effective, eco-friendly and sustainable. However, further research is needed at molecular and physiological levels of the microorganisms regarding the chromium biosorption.

\section{References}

1. Ackerley, D.F., C.F. Gonzalez, C.H. Park, R. Blake, A. Keyhan and A. Matin, 2004. Chromate-reducing properties of soluble flavoproteins from Pseudomonas putida and Escherichia coli, Applied and Environmental Microbiology, 70: 873-888.

2. APHA, 2005. Standard methods for the examination of water and wastewater, $21^{\text {st }}$ edition, American water works association, Water Environment federation, Washington DC.

3. Babich H., M. Schiffen Bauer and G. Statzky, 1982. Effect of sterilization method on toxicity of $\mathrm{Cr} 3+$ and Cr 6+ to fungi. Microbios letters, 20: 55-64.

4. Basu M., S. Bhattacharya and A.K. Paul, 1997. Isolation and characterization of chromium resistant bacteria from tannery effluent. Bull. Environ. Conta. Toxicol., 58: 535-542.

5. Beureau of Indian Standards, BIS 2009. Indian Standard Drinking Water Specification (IS: 10500), New Delhi.

6. Buljan, J and I. Kral, 2011. "Introduction to treatment of tannery effluents", United Nations Industrial Development Organization (UNIDO), Vienna.

7. Camargo, F.A.O., F.M. Bento, B.C. Okeke, and W.T. Frankenberger, 2003. Chromate reduction by chromium resistant bacteria isolated from soils contaminated with dichromate J. Environ. Qual., 32: 1228-1233.

8. Diels, I. and K. Mergeay, 1990. DNA probe-mediated dectection of resistant bacteria from soils highly polluted by heavy metals App. Environ. Microbiol., 56: 14851491.

9. Fadali, O.A., Y.H. Magdy, A.A.M Daifullah, E.E. Ebrahiema, and M.M. Nassar, 2005. Removal of chromium from tannery effluents by adsorption. $J$. Enviorn Sci. and Heatlth., 39: 465-472.

10. Frankfurt, G 2002. "Treatment of Tannery Wastewater" 30: $115-120$.

11. Gadd G, M. 1990. Heavy metal accumulation by bacteria and other microorganisms. Experiential, 46: 834-840.
12. Jalandhar, 2008." Biological Treatment of Tannery Waste Water for Sulphide Removal", Int. J. Chem. Sci. 6: 472-486.

13. Krantz, D and B. Kifferstein, 2002. Water Pollution and Society, $220-238$.

14. Kuyucak, N. and B. Volesky, 1998. Biosorbents for recovery of metals from industrial solution. Biotechnol. Lett., 10: 137-142.

15. Megharaj. M., S. Avudainayagam, and R. Naidu, 2003. Toxicity of hexavalentchromium and its reduction by bacteria isolated from soil contaminated with tannery waste. Curr. Microbiol., 47: 51-54.

16. Pattanapipitpaisal, P., A.N., Mabbett, J.A. Finlay, A.J. Beswick , M. Paterson-Beedle, and Essa. 2002. Reduction of $\mathrm{Cr}(\mathrm{VI})$ and bioaccumulation of chromium by Gram-positive and Gram-negative microorganisms not previously exposed to Cr-stress. Environmental Technology, 23: 731-745.

17. Rehman A., F.R. Shakorri, and A.R. Shakoori, 2008. Heavy metal resistant freshwater climate, Euplotes mutabilis, isolated from industrial effluents has potential to decontaminate wastewater of toxic metals. Bioresource Technology. 99: 3890-3895.

18. Reid I.D., E.E Chao and PSS Dawson, 1985. Lignin degradation by Phanerochaete chryosporium in agitated cultures. Can J Microbiol 31: 88-90.

19. Romaneko V.I and V.N. Koren'Ken, 1977. A pure culture of bacteria utilizing chromates and bichromates as hydrogen acceptors in growth under anaerobic conditions. Mikrobiologiya, 46: 414-417.

20. Soha Farag and Sahar Zaki, 2010. Identification of bacterial strains from tannery effluent and reduction of hexavalent chromium. J. Environ. Biol., 31: 877-882

21. Srinath T., S. Garg and K. Ramteke, 2002, Chromium VI accumulation by Bacillus circulans: Effect of growth conditions. Indian J. Microbiol., 42: 141-146.

22. Sultan S and S. Hasnain, 2007. Reduction of toxic hexavalent chromium by Ochrobactrum intermedium strain SDCr-5 stimulated by heavy metals, Bioresource Technology, 98: 340-344.

23. Tripathi. M., S. Vikram, R.K. Jain and S.k. Garg, 2011. Isolation and growth characteristics of chromium (VI) and entachlorophenol tolerant bacterial isolate from treated tannery effluent for its possible use in simultaneous bioremediation. Indian J. Microbiol., 51: 61-69.

24. Vieira, R.H. and B. Volesky, 2000. Biosorption: A solution to pollution? Int. microbial., 31: 17-24.

25. Volesky, B., 1994. Advances in biosorption of metals: Selection of biomas types. FEMS microbial. Rev., 14: 291-302.

26. Zhiguo He., Fengling Gao, Tao Sha, Yuchua Hu, Chao $\mathrm{He}, 2009$. Isolation and characterization of a $\mathrm{Cr}(\mathrm{VI})$ reduction ochrobactrum sp. strain $\mathrm{CSCr}-3$ from chromium landfill J. Hazar. Mat., 163: 869-873. 